\title{
Simulation Models of Production Plants as a Tool for Implementation of the Di- gital Twin Concept into Production
}

\author{
Erika Sujová ${ }^{1}$, Daniela Vysloužilová 2 , Helena Čierna ${ }^{1}$, Roman Bambura ${ }^{1}$ \\ ${ }^{1}$ Faculty of Technology, Technical University in Zvolen, Studentská 26, 96001 Zvolen. Slovak Republic. E-mail: \\ erika.sujova@tuzvo.sk,cierna@tuzvo.sk,bambura.r@gmail.com \\ ${ }^{2}$ Faculty of Production Technology and Management, J. E. Purkyne University in Usti nad Labem. Pasteurova \\ 3334/7, 40001 Usti nad Labem. Czech Republic. E-mail: daniela.vyslouzilova@ujep.cz
}

The aim of the paper is to introduce the digital twin concept as part of the Industry 4.0 strategy. In the form of a case study, the procedure and outputs of the simulation of a specific production plant together with its intermediate storage and output for the next plant are presented. In the research part is presented a simulation model of production lines and intermediate stock with material flow representation. At the beginning of the research the analysis of production and logistics processes was carried out. The next part describes the programming methods used to record and redirect material flows between individual lines and stock. The simulation method using simulated production line models enables the digitization of dynamic production processes in enterprises. We expect that in the coming years there will be an increase in demand for the creation of simulation models of production systems in modern manufacturing companies that will try to implement the Industry 4.0 strategy and thus increase their competitiveness.

Keywords: Method of Simulation, Digital Twin, Production Plant, Material Flow, Industry 4.0

\section{Introduction}

Currently, new technologies are developing very rapidly and enter into our lives and into industrial processes. Digitalization and automation are finding their way into various industrial sectors. The megatrend of digitalization covers many areas of today's life such as production, which is of particular economic importance. In this context, the topic of the fourth industrial revolution, known as Industry 4.0 (I 4.0) or smart manufacturing, has continued to develop in recent years [1]. We live in an era when we are significantly confronted with new social trends which affect the living environment, sustainable life, migration processes, global social changes, and economic innovations, as well as new technologies and more efficient use of artificial intelligence [2]. Industry 4.0 also brings fundamental changes in production and human society that deserves ethical recognition and solutions. We perceive the future not only as a scientific and technological challenge, but also as an issue of ethical importance and potential ethical risks. Therefore, the civilization changes, such as the adaptation to the parameters of a new society under Industry 4.0, call for ethical caution and moral sensibility in order to reduce, or even eliminate, potential negative impacts on humans and their existential conditions.

Development in the industry has been heading by improving the production processes from automation to their digitization. The latest trend in businesses is implementation of the Industry 4.0 strategy, which predicts the future development of digital production. Many authors deal with the characteristics and the definition of the concept of Industry 4.0. Bauer [3] has defined Industry 4.0 like an intelligent real-time, horizontal and vertical integration of humans and machines with objects and information and communication technology systems ("digitalization") to enable a flexible and dynamic management of complex systems [3]. Industry 4.0 philosophy and the associated method of digital factory require a wide range of tasks and skills to be managed for their successful application and efficient operating. One of the key competencies for their reliable operation is mastering computer simulation of various logistics processes that take place within the enterprise [4].

Simulation is the reproduction of a real system containing dynamic processes in simulation models. In a broader sense, simulation involves the preparation, implementation and evaluation of specific experiments using a simulation model. The model is a simplified replica of a planned or real system characterized by processes in another system. Tecnomatix Plan Simulation (TPS) is a simulation tool that helps to create digital models for systems such as production to generate system characteristics and optimize performance. Digital models allow experimentation with scenarios without disturbing existing production. They can also be used in the planning process long before the changes are introduced into the production 
process [4]. The Tecnomatix solution through simulations optimizes business processes that determine the ability to deliver the product faster. Tecnomatix makes it possible to match the production capacities with the proposed intent from product development to delivery to reduce the lengthy introduction of processes, thereby improving their quality, and ultimately to increase company flexibility, market share and brand value. Creating a simulation model is currently a major challenge for businesses with ambition to engage in the modernization of their processes through the latest trend in enterprise digitization, Industry 4.0.

\section{Literature review about Digital Twin phe- nomenon}

Industry 4.0 is based on the so-called Cyber-Physical Systems (CPS), which consist of a physical and a virtual part. Physical systems include actuators and sensors that collect data and transmit it over a network. Virtual counterparts of physical systems map physical parts, monitor them, and use their data to control the actuators of the physical element [5], creating a closed-loop circuit. Digital twins (DT) are often discussed in this increasingly complex work environment. They also implement the mentioned closedloop approach [6], but focus on simulating different scenarios. DT contains various types of data such as product specifications and designs, production process models, performance data and other knowledge representations [7]. Thus, due to this consolidation of heterogeneous data, DT can be considered a multidimensional and multilayered cognitive artefact. A cognitive artefact is a man-made object that contains externalized knowledge or memories that help accomplish a task [8].

The original purpose of DT was to determine the condition and behaviour of the aircraft by digital mirroring based on mathematical models, historical and current data. Since 2012, DT has also been discussed in other industries. The application of this concept was extended in 2014 from Product Life Cycle Management (PLM) to the manufacturing area [9]. Since then, the number of scientific publications on the subject has increased significantly in each subsequent year [10]. While initially three basic elements were identified (physical component, virtual component and interconnection between them) five conceptual components were later proposed [10]. As such, DT consists of a physical entity, a virtual entity, a system of services, data, and connections between them, all of which are equally important. Only two-way data exchange between virtual and physical objects allows the DT concept [11]. According to this understanding, the data, apart from the original three parts, constitute a central component of DT, since they are necessary to generate new knowledge. This concludes that at an abstract level, DT can be considered a cognitive artefact for the manufacturing context in industry 4.0. The DT concept has evolved into a virtual-physical concept that is related to CPS and the latest definition of human-to-industry interface 4.0. On this basis, we conclude that DTs are a comprehensive management tool for CPS that explicitly reflects human interactions. DT can therefore be characterized as a sociotechnical systém [12].

As an evolving digital replica of a physical system, Digital Twin becomes a key technology enabling cyber production, as shown in Figure 1. The Digital Twin cannot be used solely to model and simulate system development to support system design or validation $[13,14]$, but can also support operational and manufacturing services to optimize operations and predict failures. The Digital Twin idea of paradigm shift is designed for an integrated vehicle health management system that allows flight safety and reliability [15]. The Digital Twin conceptual model is presented by integrating structural deformation and temperature calculations to predict the life of aircraft structure [16]. A low-energy health monitoring system with data purification has been developed for a cybernetic machine [17]. As a tailor-made model, Digital Twin employs data-based simulation models based on physics and intelligence to offer valuable clues about how an error would occur and how to proceed. To ensure good consistency between the physical system of interest and the digital model created, it is important to explore how to design the Digital Twin model to properly represent the real conditions associated with the physical system [18].

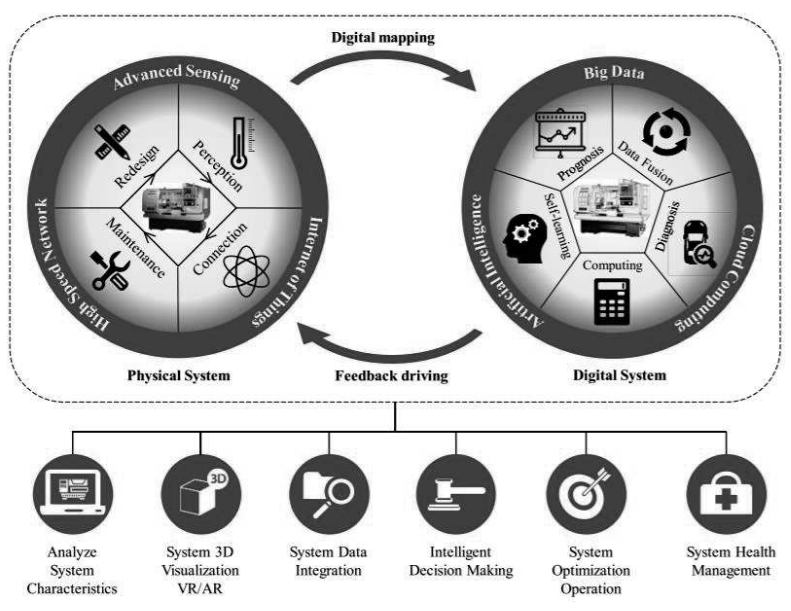

Fig. 1 The Digital Twin architecture for digital manufacturing [18]

\section{Materials and methods}

In the research we dealt with the process of creating a digital twin of a specific production plant by creating its digital simulation model. It was a model of the Machining department in a company engaged in the 
production of brake calipers for the automotive sector. Tecnomatix Plant Simulation (TPS) was used to design a digital twin of real production lines and logistics. The research was carried out through a case study on selected lines of analyzed plant.

\subsection{Simulation procedure}

Simulation of the production line in the TPS environment is an effective method for solving our research objectives aimed at analysing the line processes efficiency. The outputs of the preformed simulation are resource statistics, from which we can determine the cost of individual workstations and thus determine the effectiveness of the solution.

Tecnomatix Plant Simulation (TPS) is a simulation tool that enables you to create digital system models to help you define the system characteristics and optimize performance. Digital models allow us to experiment with scenarios without disturbing the existing production being able to use them in the planning process long before the changes are introduced into the production process. Extensive analytical tools, such as narrow space analyses, statistics and graphs allow you to evaluate different production scenarios. Simulation of results provides the information needed for quick and reliable decisions in the initial stages of production planning. Using TPS, we can model and simulate manufacturing systems and their processes. In addition, TPS allows you to optimize the material flow, resource utilization, and logistics for levels of production plant planning, through local plans to specific lines [19].

\subsection{Analysis of production and logistics processes}

The research is carried out as a case study of a production plant in a Slovak machine-building company dealing with the components for the automotive sector production. Due to sensitivity and data protection, we do not provide the name of the plant, specific lines and analyzed components.

The first step in creating the simulation model was to analyze the manufacturing processes. In the research we solved five production lines in the Machining department, where machining operations are performed on the brake caliper holders. We named the lines LA, LB, LC, LD and LE. Each line consisted of one to three machines, the first machine for initial machining and the rest for finishing. Machining operations and transfer of parts between stations are performed automatically. Tables 1 and 2 show the individual processing times we worked on to create the models [20].

Based on the production plan, the products are delivered from stock to individual lines for the first machine tools. Delivery of the product to these machines from the warehouse is ensured by a forklift, which also ensures transportation of material to the Galvanization department after the completion. After the first machining, the product is placed in an intermediate warehouse, where on the basis of the established production plan are delivered subsequently the products for the second and last machining. LC and LA lines were selected to create a case study.

Tab. 1 Machining processes for the LC line [20]

\begin{tabular}{|c|c|c|}
\hline Station & Process & Time \\
\hline S1 & loading and unloading & $21 \mathrm{~s}$ \\
\hline S2 & $\begin{array}{l}\text { threading M6x1 } \\
\text { drilling D5,05 / } 8 \\
\text { milling D20 }\end{array}$ & $33.4 \mathrm{~s}$ \\
\hline S3 & $\begin{array}{l}\text { drilling (drill D8) } \\
\text { drilling (drill D3) }\end{array}$ & $27 \mathrm{~s}$ \\
\hline S4 & roughing (rod D56,6) & $15.9 \mathrm{~s}$ \\
\hline S5 & milling Ø310 & $26.5 \mathrm{~s}$ \\
\hline S6 & $\begin{array}{l}\text { the whole stab of the dus- } \\
\text { ter }\end{array}$ & $24.7 \mathrm{~s}$ \\
\hline S7 & jigging Ø57 & $22.8 \mathrm{~s}$ \\
\hline S8 & groove TK D59,5 & $22.4 \mathrm{~s}$ \\
\hline S9 & $\begin{array}{l}\text { milling D16 } \\
\text { drilling D 18,5 }\end{array}$ & $34.6 \mathrm{~s}$ \\
\hline S10 & rinse & $5 \mathrm{~s}$ \\
\hline
\end{tabular}

Tab. 2 Machining processes for the LA line [20]

\begin{tabular}{|c|c|c|}
\hline Station & Process & Time \\
\hline \multirow{2}{*}{ S1 } & $\begin{array}{c}\text { loading and unloading of } \\
\text { parts }\end{array}$ & $22 \mathrm{~s}$ \\
\hline \multirow{2}{*}{ S2 } & milling D 50 & $17.3 \mathrm{~s}$ \\
& side time & $2.9 \mathrm{~s}$ \\
\hline \multirow{3}{*}{ S3 } & thread M14x2 & $7.9 \mathrm{~s}$ \\
& drilling D12,05/16 & $9.3 \mathrm{~s}$ \\
& side time & $4.5 \mathrm{~s}$ \\
\hline \multirow{3}{*}{ S4 } & thread formation & $8.6 \mathrm{~s}$ \\
& M9x1,25 & $8.5 \mathrm{~s}$ \\
& drilling D 7.8 & $4.9 \mathrm{~s}$ \\
\hline
\end{tabular}

\subsection{Creation a simulation model as a tool for creating} a digital twin

When designing the model we used real data, which were measured in production in cooperation with the company employee. It was necessary to collect relevant information when creating the simulation model of the hall. These were data on individual lines (processes, operating hours - tables 2 and 3), routes (dimensions of logistic routes) and logistic processes.

Simulation model Machining department consists of five modules representing each section of the operation. We divide them into the main module and submodules. The main module represents the complete manufacturing plant and thus the simulation model as a whole. The sub-modules are divided into: produ- 
ction lines, warehouse, intermediate storage and output for the subsequent Galvanizing department. Using the above modules, we can keep the simulation clear. It also provides the possibility of easier work with individual sections or their modifications. For a clear description of our research conducted in the case study, we chose a module covering LA and LC machining lines, including in-process logistics, intermediate storage and output in the module - Figure 2. The module contains buffer elements that are reserved for material containers. Buffer_LC_IN represents where the material is unloaded and which will then be processed on the appropriate line. In the case of LC_Gal and LC_MS, this is the space for the material to be processed, which is waiting for transport to the intermediate storage or to galvanization [20].

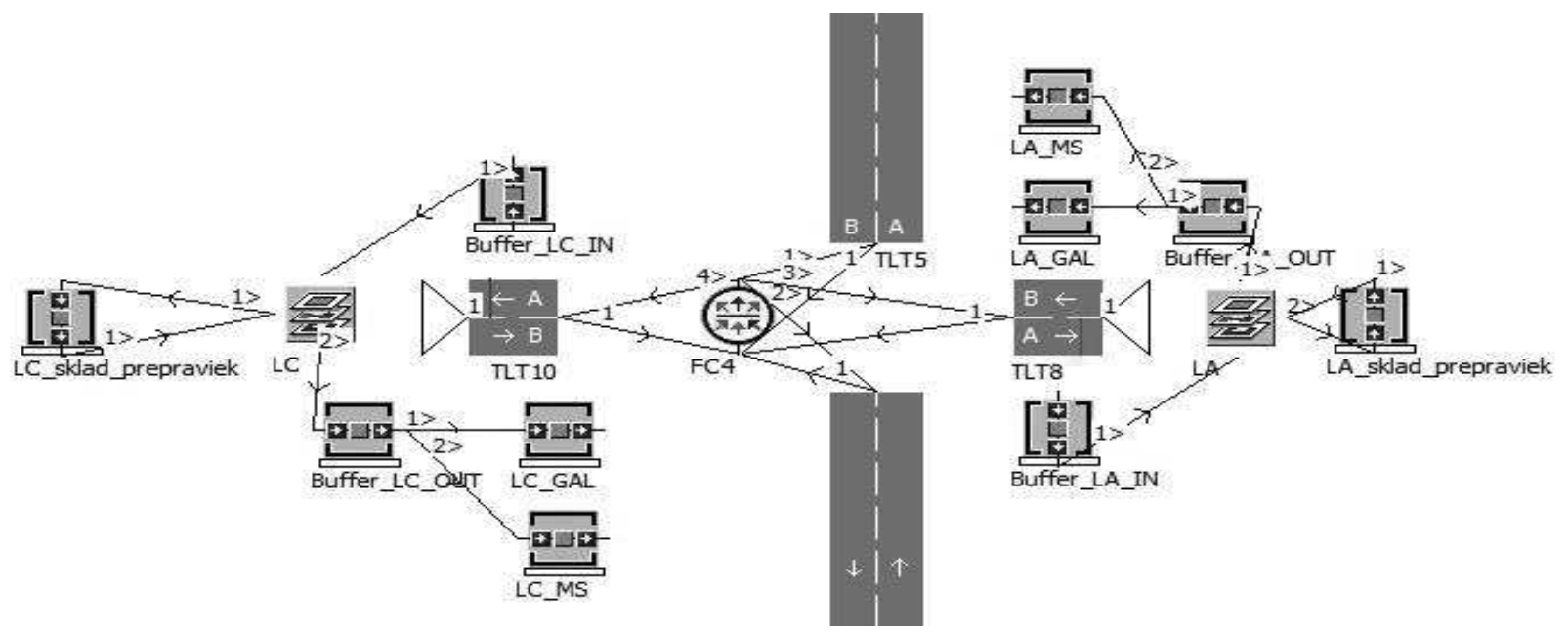

Fig. 2 Simulation model of the module with LA and LC machining lines, in-process logistics, intermediate storage and output

Figure 3 shows a simulation model of an LC line consisting of two machines. For each line, there is a table in which the product name is entered and how many pieces have been processed on that line.

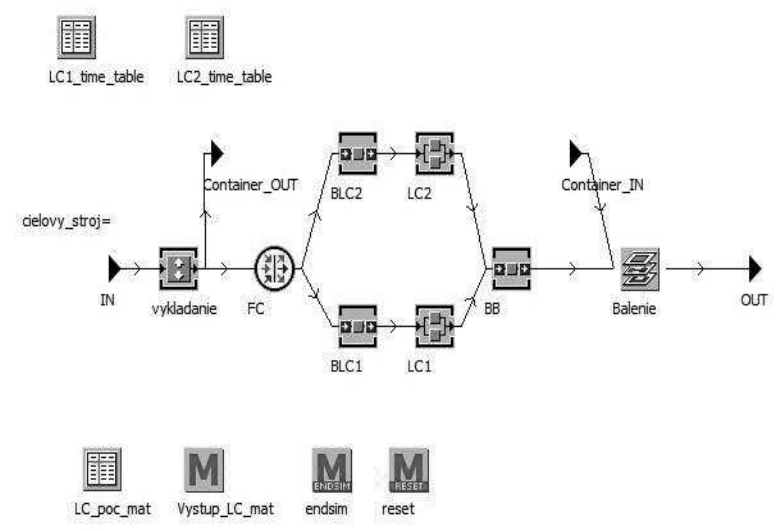

Fig. 3 Simulation model of LC line in TPS

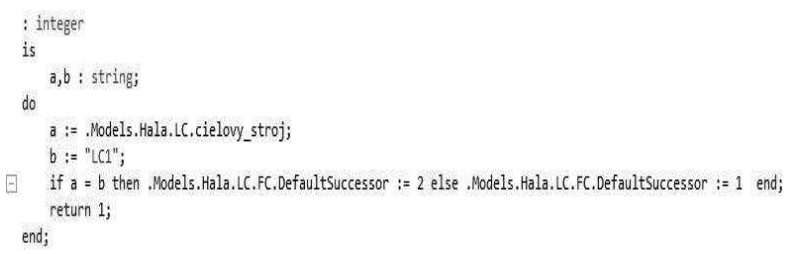

Fig. 4 Method for sorting material through Flow Control [20]

The sorting of the material into the respective machines in the simulation model is controlled by the Flow Control element. This element contains Method that provides this function (Figure 4) [20].
The requirement to create spreadsheet outputs from individual lines is necessary for other creation processes of digital twin of production. The following are examples of obtained outputs from line simulation models that will be used to create a digital twin.

\subsection{Simulation results}

The simulation models have been programmed to record the actual production status in the summary tables for registering the outputs from the Machining department to Galvanization department. Two summary tables were created from the output for Galvanization department in the simulation model. The first table (Table 3) shows the total number of containers from the individual Machining department lines that went to Galvanization department.

Tab. 3 Table summarizing the number of containers from individual lines

\begin{tabular}{|l|l|l|}
\hline & String 1 & Integer 2 \\
\hline String & Container & Number \\
\hline 1 & LA & 85 \\
\hline 2 & LB & 29 \\
\hline 3 & LC & 95 \\
\hline 4 & LE & 149 \\
\hline 5 & LD & 149 \\
\hline
\end{tabular}

In order to get more information and a better overview of what material left Machining department, a second table was programmed in TPS (Table 4). All containers that have left the Machining department are recorded in this table during the simulation. From the 
table it is then possible to read from which line the container came and what material was stored there, together with the number of machined pieces and the indicated time and date when this occurred.

Table 4 is provided by the method shown in Figure 5. This method works by comparing the entered names with the container name and then registering the required data in the table.

As was presented in this chapter on the example of creating tables of statistical outputs from analyzed lines, it is possible to program data collection in simulation models and create outputs in the form of tables or graphical outputs. Writing of the required data to the tables, as shown in the examples, is provided by methods (Figure 5). Data are written to the tables in the program and then are automatically written to the Excel file after the simulation is completed. And they then make the output which is subsequently used in the digital twin in real time - online. Working with data transmission, their analysis and decisions about the next process on the line, is the goal of the digital twin, which will be compiled in the future to control the processes in the analyzed operation. The data transmission will be performed using sensors, suitably located on the line. The created simulation models provide high flexibility in changing the capacity of the workstation, the number of products, materials, transport and machining speed. It is possible to implement the changed data into created models, which allow to create more detailed models with automatic recalculation of statistical data. Such information and data can be used by technologists, production planners or economists for various areas of business processes. The risk of misrepresentation of reality in the simulation model may be an inaccurately created model or incorrectly entered data.
Tab. 4 List of materials from the output for Galvanization department

\begin{tabular}{|l|l|l|l|}
\hline Container & Product & Units & Time and date \\
\hline $\begin{array}{l}\text { Conta- } \\
\text { iner_LB }\end{array}$ & LB_P_1 & 192 & $2.1 .140: 47$ \\
\hline $\begin{array}{l}\text { Conta- } \\
\text { iner_LB }\end{array}$ & LB_P_1 & 192 & $2.1 .140: 47$ \\
\hline $\begin{array}{l}\text { Conta- } \\
\text { iner_LB }\end{array}$ & LB_P_1 & 192 & $2.1 .140: 47$ \\
\hline $\begin{array}{l}\text { Conta- } \\
\text { iner_LE }\end{array}$ & LE_P_1 & 90 & $2.1 .140: 57$ \\
\hline $\begin{array}{l}\text { Conta- } \\
\text { iner_LE }\end{array}$ & LE_P_1 & 90 & $2.1 .140: 57$ \\
\hline $\begin{array}{l}\text { Conta- } \\
\text { iner_LE }\end{array}$ & LE_P_1 & 90 & $2.1 .140: 57$ \\
\hline $\begin{array}{l}\text { Conta- } \\
\text { iner_LE }\end{array}$ & LE_P_1 & 90 & $2.1 .141: 28$ \\
\hline $\begin{array}{l}\text { Conta- } \\
\text { iner_LE }\end{array}$ & LE_P_1 & 90 & $2.1 .142: 06$ \\
\hline $\begin{array}{l}\text { Conta- } \\
\text { iner_LE }\end{array}$ & LE_P_1 & 90 & $2.1 .142: 06$ \\
\hline $\begin{array}{l}\text { Conta- } \\
\text { iner_LE }\end{array}$ & LE_P_1 & 90 & $2.1 .142: 06$ \\
\hline $\begin{array}{l}\text { Conta- } \\
\text { iner_LE }\end{array}$ & LE_P_1 & 90 & $2.1 .142: 38$ \\
\hline $\begin{array}{l}\text { Conta- } \\
\text { iner_LA }\end{array}$ & LA_P_1 & 189 & $2.1 .142: 40$ \\
\hline $\begin{array}{l}\text { Conta- } \\
\text { iner_LA }\end{array}$ & LA_P_1 & 189 & $2.1 .142: 40$ \\
\hline $\begin{array}{l}\text { Conta- } \\
\text { iner_LA }\end{array}$ & LA_P_1 & 189 & $2.1 .142: 40$ \\
\hline $\begin{array}{l}\text { Conta- } \\
\text { iner_LB }\end{array}$ & LB_P_1 & 192 & $2.1 .142: 44$ \\
\hline $\begin{array}{l}\text { Conta- } \\
\text { iner_LB }\end{array}$ & LB_P_1 & 192 & $2.1 .142: 44$ \\
\hline $\begin{array}{l}\text { Conta- } \\
\text { iner_LB }\end{array}$ & LB_P_1 & 192 & $2.1 .142: 44$ \\
\hline
\end{tabular}

is

NextRow, $x$ : integer;

do

$n:=$ @.getattrvalue (3);

$x:=$ @. XDim;

Models.Hala.Galvanika.Galvanika_stat $[1,1]:="$ LA" $^{\prime}$; Models.Hala.Galvanika.Galvanika_stat $[1,2]:=" L B "$. -Models.Hala.Galvanika.Galvanika_stat $[1,3]:=" L C "$. Models.Hala.Galvanika.Galvanika stat $[1,4]:=$ "Lif" .Models.Hala.Galvanika.Galvanika_stat $[1,5]:=" L D^{*}$.

if @. name= "container LA"then

Models.Hala.Galvanika.Galvanika_stat[2,1]:= Models.Hala.Galvanika.Galvanika_stat[2,1] + 1

elseif @-name= "Container LB"then

.Models.Hala.Galvanika.GaIvanika_stat $[2,2]:=$.Models.Hala.Galvanika.Galvanika_stat[2,2] + 1

elseif @.name= "Container LC"then

.Models.Hala.Galvanika.Galvanika_stat[2,3]:= Models.Hala.Galvanika.Galvanika_stat[2,3] + 1

elseif @. name= "Container LE"then

Models.Hala.Galvanika.GaIvanika_stat[2,4]:= Models.Hala.Galvanika.Galvanika_stat[2,4] + 1

elseif (Mame= "Container

Models.Hala.Galvanika.Galvanika_stat $[2,5]:=$.Models.Hala.Galvanika.Galvanika_stat[2,5] + 1

end;

NextRow : = Models.Hala.Galvanika.stat.ydim + 1 ;

Models.Hala.Galvanika.stat [1, NextRow $]$ := @.name;

Models.Hala.Galvanika.stat $[2$, NextRow $]:=n$;

Models. Hala.Galvanika.stat $[3$, NextRow $]:=x ;$

Models. Hala.Galvanika.stat [4,NextRow] :=eventController.date + eventController.simtime;

end:

Fig. 5 Method for creating a list of materials from the output for Galvanization department [20] 


\section{Conclusion}

The aim of the research was an initial analysis of the processes on the line, the creation of a simulation model as a basis for the creation of a digital twin. The digital twin is a digital image of a real production system. The benefit of the digital twin is to depict processes in a simulation model and optimize them, streamline and increase productivity of production processes, and identify bottlenecks in production. Using the simulation model is it possible to monitor the current state of production in operation and in case of any changes to compare the results between real and simulated - fictitious model. It allows to identify potential shortcomings and to improve future proposals for change before they are actually put into practice. The advantage of the created simulation model is the possibility to simulate a longer period of time, by means of which we can get a general overview of processes in operation also over a longer period of time. Given that real data was used in the creation of the digital twin, the company is able to compare the simulation results with the data which are available from specific production analyzes.

Industry 4.0 constitutes also a fundamental turning point that deserves ethical appreciation and solutions. The peculiarities of this paradigm should also be explored within ethics and enter, in a constructive manner, the discourse in the area of science and research, both within professional socialization and within the area of institutionalization of ethical tools in order to minimize, to a maximum possible extent, the ethical risks and potential negative consequences of new technologies and use of digital data in relation to customers and partners. New ethical responsibility will have to be defined in relation to employees, stakeholders, and the environment. In order to implement these plans, it will be necessary to develop and form new dispositions and new approaches. The participatory role of the applied ethics, ethical consulting, and ethical expertise should be compatible with such unusual requirements and new mission.

The digital version of the Machining Department was designed using the Tecnomatix Plant Simulation program. The model consisted of several modules that represented individual sections of the operation. This division of the model ensured the transparency of the simulation model and in the future simplified modifications of the simulation without the need for major interventions into the production hall model. The advantage is that the model itself creates MovableUnits -MUs, which represent individual products, that means, it does not need to do manually. The simulation model assists in optimizing, streamlining and increasing the productivity of production processes, and can be used to modernize and introduce changes in production.

\section{Acknowledgement}

The authors would like to thank Agency APVV for their support of the APVV-17-0400 project "Enhancing the Ethical Environment in Slovakia (Institutional Procedures, Actors, Risks, Strategies)". This paper was created as part of the project.

\section{References}

[1] WACHE, H., DINTER, B. (2020). The Digital Twin - Birth of an Integrated System in the Digital Age. In. Proceedings of the 53rd Hawaii International Conference on System Sciences, pp. 5452 5460.

[2] SHUAI D. (2019) Research on Distribution Automation Based on Power Supply Reliability. In: Manufacturing Technology, Vol. 19, No. 6, pp. 923 - 929, Ústí nad Labem. Czech Republic. ISSN 1213-2489.

[3] BAUER, W., SCHLUND, S., MARRENBACH, D., GANSCHAR, O. (2014). Industrie 4.0 - Volkswirtschaftliches Potenzialfür Deutscbland. Studie. [online] [12.02.2019]. Available at: https://www.produktionsarbeit.de/content/dam/produktionsar-

beit/de/documents/Studie-Industrie-4-0-

Volkswirtschaftliches-Potential-fuer-Deutschland.pdf

[4] NERADILOVA, H., FEDORKO, G. (2017). Simulation of the supply of workplaces by the $\mathrm{AGV}$ in the digital factory. In TRANSCOM 2017: International scientific conference on sustainable, modern and safe transport. Procedia Engineering. 2017, doi: 10.1016/j.proeng.2017.06.110. pp.638 - 643. ISBN 9781510843349.

[5] DIEZ-OLIVAN, A., DEL SER, J., GALAR, D., SEIRRA, B. (2018). Data fusion and machine learning for industrial prognosis: Trends and perspectives towards Industry 4.0. Information Fusion 50, https:// doi.org/10.1016/j.inffus. 10.005, pp. 92-111. ISSN 1566-2535.

[6] PRAUSE, M., WEIGAND, J. (2016). Industry 4.0 and Object-Oriented Development: Incremental and Architectural Change. Journal of technology management \& innovation. ISSN 0718-2724. Vol. 1, Issue 2, 2016. pp.104 -110. ISSN 07182724.

[7] TAO, F., CHENG, J. Q. Qi, ZHANG, M., ZHANG, H. SUI, F. (2018). Digital twin-driven product design, manufacturing and service with big data, International Journal of Advanced $\mathrm{Ma}$ nufacturing Technology 94(9-12), pp. 3563-3576. ISSN 1433-3015. 
[8] NORMAN, D.A.,(1993). Things That Make Us Smart: Defending Human Attributes in the Age of the Machine, Addison-Wesley Longman Publishing Co., Inc., Boston, MA, USA. ISBN 978-0-20162695-7.

[9] GRIEVES, M. (2014). Digital Twin: Manufacturing Excellence through Virtual Factory Replication.

[10] DRBÚL, M., STANČEKOVÁ, D., BABÍK, O., HOLUBJAK, J., GŐRŐGOVÁ, I., VARGA, D. (2016). Simulation Possibilities of 3D Measuring in Progressive Control of Production. In: Manufacturing Technology, Vol. 16 (1), pp. 53 - 58, Ústí nad Labem. Czech Republic. ISSN 1213-2489.

[11] ALAM, K.M., EL SADDIK, A. (2017). C2PS: A digital twin architecture reference model for the cloud-based cyberphysical systems, IEEE Access, 5, pp. 2050-2062. ISSN 2169-3536.

[12] KRITZINGER, W., KARNER, M., TRAAR, G., HENJES, J., SIHN, W. (2018). Digital Twin in manufacturing: A categorical literature review and classification, IFAC-PapersOnLine 51(11), pp. 1016-1022. ISSN: 2405-8963

[13] SCHLEICH, B., ANWER, N., MATHIEU, L., WARTZACK, S. (2017). Shaping the Digital Twin for Design and Production Engineering. CIRP Annals 66 (1): 141-144. ISSN: 0007-8506.

[14] TAO, F., SUI, F., LIU, A., ZHANG, Q. Qi, M., SONG, B., NEE, A. Y. C. (2018). Digital TwinDriven Product Design Framework. International Journal of Production Research 56: 1-19. ISSN 0020-7543.
[15] GLAESSGEN, E., STARGEL, D. (2012). The Digital Twin Paradigm for Future NASA and US Air Force Vehicles. In 53rd AIAA/ASME/ASCE/AHS/ASC Structures, Structural Dynamics and Materials Conference 20th AIAA/ASME/AHS Adaptive Structures Conference 14th $A L A A$ (p. 1818).

[16] TUEGEL, E. J., INGRAFFEA, A. R., EASON, T. G., SPOTTSWOOD, S. M. (2011). Reengineering Aircraft Structural Life Prediction Using a Digital Twin. International Journal of Aerospace Engineering, pp 1-14. ISSN: 16875974.

[17] WU, Y.M., XU, Y.X., LUO, L.F., ZHANG, H., ZHAO, X.D. (2018). Research on evolution balancing for product family assembly line in big data environment. In: Manufacturing Technology, Vol. 18 (2), pp. 337-342. Ústí nad Labem. Czech Republic. ISSN 1213-2489.

[18] WANG, J., YE, L., GAO, R.X., LI, Ch., ZHANG, L. (2019) Digital Twin for rotating machinery fault diagnosis in smart Manufacturing. International Journal of Production Research, 57:12, 3920-3934, DOI: 10.1080/00207543.2018.1552032. ISSN 0020_ 7543.

[19] BANGSOW, S. (2010). Manufacturing Simulation with Plant Simulation and Sim Talk, pp- 289. Springer-Verlag Berlin Heidelberg. ISBN 9783642050732

[20] POLERECKÝ, P. (2018). Simulation of production processes and logistics in production plant. Diploma thesiss. Technical university in Zvolen, 63p. 